\title{
ASSESSMENT OF GROUNDWATER QUALITY FOR IRRIGATION USE
}

\author{
C. Sarala \\ Associate Professor, Centre for Water Resources, Institute of Science \& Technology, Jawaharlal Nehru Technological \\ University Hyderabad, A.P, India, sarala2006@gmail.com.
}

\begin{abstract}
The availability of groundwater, namely fresh water is too less. This situation provokes the scientific community to further research in the field groundwater exploration of fresh water and natural recharge estimation, which are the most important components essential to formulate dependable groundwater management strategies in scarcity, affected regions. Hydrochemical studies were conducted in Chinnaeru river basin of Nalgonda District, Andhra Pradesh, India. Water samples from 28 locations were collected from bore wells during May 2011 and analyzed for different physico-chemical parameters. Based on various indices and water quality standards, the water is classified for safe drinking and irrigation uses. The concentration of fluoride in groundwater ranges from 0.4-2.9 mg/l. Piper diagram reflect that the water belong to $\mathrm{Ca}^{+2}-\mathrm{Mg}^{+2}-\mathrm{HCO}_{3}^{-}$to $\mathrm{Na}^{+}-\mathrm{HCO}_{3}^{-}$types. The Wilcox diagram suggests that most of the samples are within the permissible limits which can be used for irrigation. High fluoride content in groundwater can be attributed to the continuous water rock interaction during the process of percolation with fluorite bearing country rocks under arid, low precipitation and high evaporation conditions of the study area. The low calcium content in rocks and soils and the presence of high levels of sodium bicarbonate in soils and waters are important factors favouring high levels of fluoride in waters. The basement rocks provide abundant sources of fluoride in the form of amphibole, biotite, fluorite and apatite. The high fluoride concentration areas are demarcated and de-fluoride plant were installed to treat the water for safe drinking purposes.
\end{abstract}

Index Terms: Groundwater, Bore wells, Wilcox diagram, Piper diagram, Fluoride content.

\section{INTRODUCTION}

Water is one of the most indispensable resources and is the elixir of life and primary cause for the origin of life on earth planet. Water constitutes about $70 \%$ of the body weight of almost all living organisms. Life is not possible on this planet without water. It exists in three states namely solid, liquid and gas. It acts as a media for both chemical and biochemical reactions and also as an internal and external medium for several organisms. About $97.2 \%$ of water on earth is salty and only $2.8 \%$ is available as fresh water from which about $20 \%$ constitutes groundwater. The main source of water in the earth is through rivers, lakes, oceans and the subsurface groundwater aquifers. Groundwater is highly valued because of certain properties not possessed by surface water. Water can be used for various purposes like domestic, agriculture, industrial and etc.

Due to increase in human population and technology growth day by day, the available storage of groundwater is over exploited without considering its adverse effect on the aquifer system, which causes depletion in water level and deterioration in quality of groundwater. The availability of groundwater, namely fresh water is too less. The storage of groundwater mostly depends on the rainfall and how much recharge is taking place during rains. But due to non-uniform distribution of rainfall and failure of monsoon in our country, the existing available groundwater resources are not able to meet the increasing demand of human population.
This situation provokes the scientific community to further research in the field groundwater exploration of fresh water and natural recharge estimation, which are the most important components essential to formulate dependable groundwater management strategies in scarcity, affected regions. The present study gives out the objectives, to estimate the cations and anions for the groundwater samples and to assess the groundwater quality by Pipers diagram and Wilcox diagram.

\section{LOCATION AND EXTENT}

In order to assess the groundwater quality for irrigation uses a Chinnaeru river basin is selected. The basin is situated $30 \mathrm{~km}$ away from Hyderabad, the capital of Andhra Pradesh State, India. Geologically the area consists of granites, gneisses and pegmatite of igneous origin belonging to the Archaean age. The study area is located between $170.38^{\prime} \mathrm{N}-170.50^{\prime} \mathrm{N}$ latitude and 780.78' - 790.96' E longitude. The granites are pink and grey in color, hard massive to foliated and well jointed. The soil cover is of well developed residual soil of weathered granite. The soil is fairly permeable with brownreddish colour. The soil can absorb most of the rain except for more intensive rains, which can cause considerable surface flow and erosion.

The groundwater occurs in the weathered granite under semiconfined conditions and the fractured solid bedrock under the groundwater table. The average depth of groundwater is about 10-12 meters. These rocks posses negligible primary porosity 
but due to secondary porosity by deep fracturing and weathering, they are rendered with a porosity and permeability, which locally form potential aquifers in the study area. The location map of the study area is shown in fig. (1).

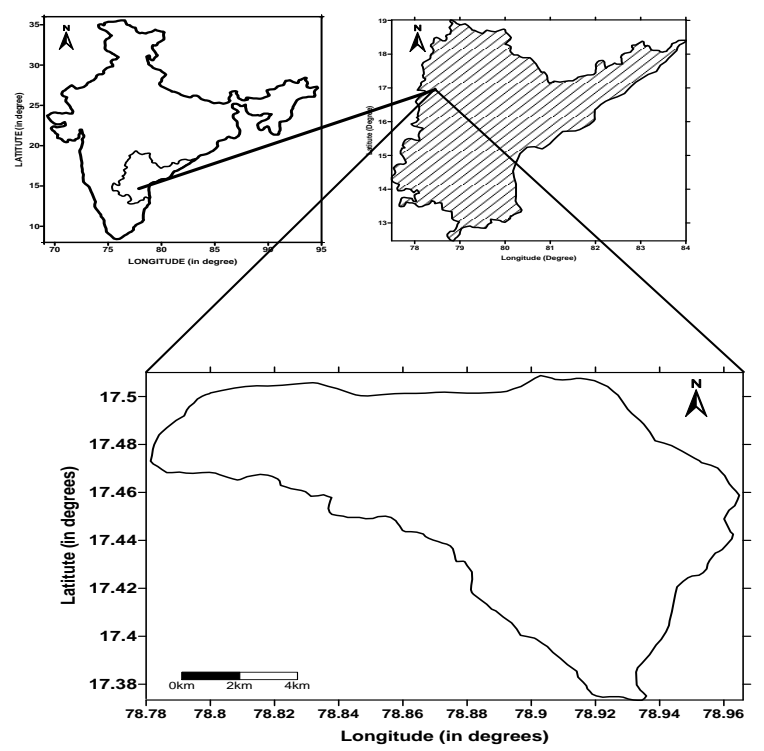

Fig.1 Location Map of the Study Area

\section{RESEARCH METHODOLOGY}

Groundwater samples were collected in pre-cleaned 1 litre polyethylene bottle following APHA, 1995 method from the bore wells, which are used for the irrigation purposes during May 2011 period. The water samples from the wells were collected after pumping out water for about $10 \mathrm{~min}$ to remove stagnant water from the well. Twenty eight groundwater samples are collected and analysed for major cations and anions. The groundwater sample locations in the study area are represented in fig. (2). The various groundwater quality parameters like $\mathrm{pH}$, Total Dissolved solids, Potassium,
Magnesium, Calcium, Chlorides, Sulphates, Carbonates, Bicarbonates, Nitrates and Fluorides are analyzed as per BIS standards. Piper diagram is also plotted to analyse the groundwater parameters. The sodium adsorption ratio in the study area is estimated by Wilcox diagram.

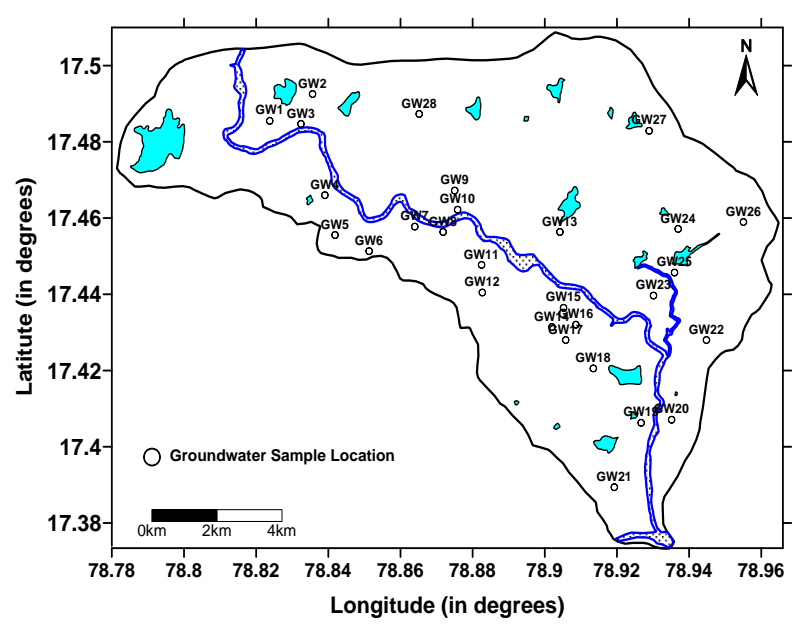

Fig.2 Groundwater Sample Locations in the Study Area

\section{RESULTS}

It has been observed from the analysis that the Nitrate concentration is exceeding the permissible limits in the groundwater samples collected at Erravattet Thanda, Gollaguda Village, Madhram Thanda 1, Madhram Thanda 3, Nagireddy palli Village, Erram palli Village and Tukkapuram Village. At Gudur Thanda, Pagidipalli Village, Gudur Village, Anamptla Village, Makhdumpalli Thanda, Madhram Thanda 3, Srinikunta Village, Bollapalligandinagar Village, Bollapalligandinagar Thanda, Suryapalli Village and Nandanam Village the fluoride concentration is exceeding the permissible limit. The groundwater quality parameter values in the study area are shown in the Table1. The average values of the each quality parameter are shown in the Table (2). 


\begin{tabular}{|c|c|c|c|c|c|c|c|c|c|c|c|c|c|c|}
\hline $\begin{array}{l}\text { Well } \\
\text { No. }\end{array}$ & Sample Location & $\mathrm{pH}$ & $\begin{array}{l}\text { EC } \\
(\mu \mathrm{s} / \mathrm{c} \\
\mathrm{m})\end{array}$ & $\begin{array}{l}\text { TDS } \\
(\mathrm{mg} / 1 \\
)\end{array}$ & $\begin{array}{l}\mathrm{Na}^{+} \\
(\mathrm{mg} / \\
1)\end{array}$ & $\begin{array}{l}\mathrm{K}^{+} \\
(\mathrm{mg} / \\
\text { l) }\end{array}$ & $\begin{array}{l}\mathrm{Mg}^{+2} \\
(\mathrm{mg} / 1 \\
)\end{array}$ & $\begin{array}{l}\mathrm{Ca}^{+2} \\
(\mathrm{mg} / \\
1)\end{array}$ & $\begin{array}{l}\mathrm{Cl}^{-} \\
(\mathrm{mg} / \mathrm{l} \\
)^{-}\end{array}$ & $\begin{array}{l}\mathrm{SO}_{4}^{-2} \\
(\mathrm{mg} / \mathrm{l} \\
)\end{array}$ & $\begin{array}{l}\mathrm{HCO}_{3}^{-} \\
(\mathrm{mg} / \mathrm{l})\end{array}$ & $\begin{array}{l}\mathrm{CO}_{3}^{-} \\
(\mathrm{mg} / \\
1)\end{array}$ & $\begin{array}{l}\mathrm{NO}_{3}^{-} \\
(\mathrm{mg} / \\
1)\end{array}$ & $\begin{array}{l}\mathrm{F}^{-} \\
(\mathrm{m} \\
\mathrm{g} / \mathrm{l})\end{array}$ \\
\hline GW1 & Gudur Thanda & 7.73 & 878 & 526.8 & 137 & 2.1 & 20.1 & 22.5 & 101 & 30.5 & 135.3 & 14 & 17.2 & 2.1 \\
\hline GW2 & Pagidipalli Village & 7.56 & 1438 & 862.8 & 189 & 3.1 & 41.5 & 116 & 418 & 55.9 & 147.2 & 15 & 52.4 & 2.7 \\
\hline GW3 & Gudur Village & 7.82 & 1370 & 490.2 & 275 & 2.8 & 40.1 & 63.1 & 240 & 72.8 & 320.4 & 32 & 27.6 & 2.8 \\
\hline GW4 & Anamptla Village & 8.23 & 635 & 381 & 131 & 6.6 & 37.5 & 85.2 & 102 & 50.2 & 342.3 & 61 & 93.5 & 1.6 \\
\hline GW5 & Erravattet Thanda & 7.36 & 1158 & 694.8 & 90.8 & 1.8 & 83.1 & 235 & 395 & 120 & 113 & 13 & 395 & 0.4 \\
\hline GW6 & Gannegani Thanda & 7.64 & 619 & 371.4 & 75 & 1.8 & 39.1 & 34.8 & 31.5 & 21.9 & 191.9 & 17 & 16.2 & 0.9 \\
\hline GW7 & Makhdumpalli Village & 7.59 & 535 & 321.4 & 53 & 1.7 & 25.1 & 46.8 & 11.9 & 10.4 & 302.2 & 32 & 13.9 & 1.4 \\
\hline GW8 & Makhdumpalli Thanda & 7.59 & 958 & 574.8 & 123 & 6.7 & 43 & 20.1 & 96.3 & 48.9 & 323.8 & 43 & 22.3 & 1.6 \\
\hline GW9 & Gollaguda Village & 7.48 & 1775 & 1065 & 169 & 117 & 42.9 & 47.7 & 202 & 101 & 214.3 & 35 & 189 & 0.4 \\
\hline GW10 & Gollaguda Thanda & 7.4 & 595 & 357 & 126 & 19.7 & 28.3 & 61.8 & 95.3 & 39.6 & 296.3 & 31 & 30.9 & 1 \\
\hline GW11 & Ravipadu Thanda & 8.17 & 630 & 380 & 76 & 1.7 & 40.6 & 34.3 & 44.7 & 35.2 & 342.5 & 32 & 20.8 & 1.3 \\
\hline GW12 & Ravipadu Village & 7.72 & 650 & 390 & 71 & 2.4 & 41.8 & 92.8 & 122 & 59.8 & 1557 & 19 & 66.3 & 0.8 \\
\hline GW13 & Anjpur Village & 7.39 & 738 & 442.8 & 164 & 4 & 40.8 & 48.7 & 182 & 58.2 & 243.8 & 34 & 50.8 & 1.3 \\
\hline GW14 & Madhram Village & 7.73 & 1095 & 657 & 101 & 3 & 47.9 & 45.2 & 138 & 102 & 207.8 & 19 & 37.2 & 1.4 \\
\hline GW15 & Madhram Thanda 1 & 7.55 & 939 & 563.4 & 73 & 5.2 & 45.2 & 113 & 153 & 126 & 165.4 & 18 & 141 & 0.6 \\
\hline GW16 & Madhram Thanda 2 & 7.54 & 534 & 320.4 & 61 & 4 & 40.2 & 69.8 & 71.9 & 31.8 & 172.4 & 30 & 50.8 & 0.9 \\
\hline GW17 & Madhram Thanda 3 & 7.52 & 811 & 486.6 & 161 & 45.8 & 63.8 & 78.9 & 145 & 55.7 & 539 & 56 & 122 & 2 \\
\hline GW18 & Srinikunta & 8.33 & 1227 & 736.2 & 255 & 4 & 36.4 & 48.2 & 153 & 77.8 & 540.3 & 70 & 14.9 & 2.2 \\
\hline GW19 & $\begin{array}{l}\text { Bollapalligandinagar } \\
\text { Village }\end{array}$ & 8.04 & 1676 & 1006 & 306 & 11.4 & 49.8 & 27.8 & 239 & 96.5 & 482.4 & 52 & 31.9 & 2.9 \\
\hline GW20 & $\begin{array}{l}\text { Bollapalligandinagar } \\
\text { Thanda }\end{array}$ & 7.99 & 1528 & 916.8 & 286 & 8.7 & 43.2 & 32.7 & 206 & 94.8 & 345.8 & 47 & 18.5 & 2.9 \\
\hline GW21 & Suryapalli Village & 7.48 & 1409 & 845.4 & 477 & 8.9 & 84.5 & 46.2 & 711 & 126 & 357.2 & 43 & 8 & 2.7 \\
\hline GW22 & Nagiredd palli Village & 7.36 & 998 & 598.8 & 167 & 2.6 & 55.3 & 114 & 365 & 109 & 98.4 & 16 & 172 & 0.8 \\
\hline GW23 & Nandanam Village & 7.78 & 1946 & 1168 & 347 & 3.3 & 45.9 & 31.8 & 301 & 112 & 409.7 & 47 & 40.5 & 2.5 \\
\hline GW24 & Nyamatupalli village & 7.51 & 1283 & 769.8 & 288 & 2.8 & 104 & 95.3 & 667 & 127 & 189.8 & 31 & 71.6 & 1.4 \\
\hline GW25 & Nyamatupalli Thanda & 10.16 & 204 & 122.4 & 36.7 & 4.7 & 6.9 & 6.2 & 14.8 & 2.9 & 119.3 & 8 & 34.2 & 0.8 \\
\hline GW26 & Erram palli Village & 7.58 & 1479 & 887.4 & 113 & 3.2 & 54.2 & 134 & 151 & 85.9 & 284.2 & 23 & 186 & 1.3 \\
\hline GW27 & Tukkapuram Village & 7.58 & 1419 & 851.4 & 148 & 2.2 & 46.8 & 107 & 261 & 71.9 & 177.3 & 17 & 107 & 1.2 \\
\hline GW28 & Bommaipalli Village & 7.65 & 1191 & 714.6 & 129 & 2.8 & 31.4 & 23.4 & 162 & 60.2 & 232.4 & 28 & 54.2 & 0.8 \\
\hline
\end{tabular}

TABLE (1) Groundwater Quality Parameters in the Study Area 
Table (2) Average Values of the Groundwater Quality parameters

\begin{tabular}{|l|l|l|l|}
\hline $\begin{array}{l}\text { Groundwater } \\
\text { Parameters }\end{array}$ & $\begin{array}{l}\text { Mini } \\
\text { mum } \\
\text { values }\end{array}$ & $\begin{array}{l}\text { Maximu } \\
\text { m values }\end{array}$ & $\begin{array}{l}\text { Average } \\
\text { values }\end{array}$ \\
\hline $\mathrm{pH}$ & 7.36 & 10.16 & 8.76 \\
\hline $\mathrm{EC}$ & 204 & 1946 & 1075 \\
\hline $\mathrm{TDS} \mathrm{mg} / \mathrm{l}$ & 122.4 & 1167 & 644.75 \\
\hline $\mathrm{Na}^{+} \mathrm{mg} / \mathrm{l}$ & 36.7 & 476.8 & 256.75 \\
\hline $\mathrm{K}^{+} \mathrm{mg} / \mathrm{l}$ & 1.7 & 116.5 & 59.1 \\
\hline $\mathrm{Mg}^{+2} \mathrm{mg} / \mathrm{l}$ & 6.9 & 103.5 & 55.2 \\
\hline $\mathrm{Ca}^{+2} \mathrm{mg} / \mathrm{l}$ & 6.2 & 235.2 & 120.7 \\
\hline $\mathrm{Cl}^{-} \mathrm{mg} / \mathrm{l}$ & 11.9 & 711 & 361.45 \\
\hline $\mathrm{SO}_{4}{ }^{-2} \mathrm{mg} / \mathrm{l}$ & 2.9 & 126 & 64.45 \\
\hline $\mathrm{HCO}_{3}{ }^{-2} \mathrm{mg} / \mathrm{l}$ & 98 & 540 & 319 \\
\hline $\mathrm{CO}_{3}{ }^{-} \mathrm{mg} / \mathrm{l}$ & 8 & 70 & 39 \\
\hline $\mathrm{NO}_{3}{ }^{-} \mathrm{mg} / \mathrm{l}$ & 8 & 395.4 & 201.7 \\
\hline $\mathrm{F}^{-} \mathrm{mg} / \mathrm{l}$ & 0.4 & 2.9 & 1.65 \\
\hline
\end{tabular}

A Piper diagram was plotted for the analyses of groundwater samples. Three types of distributions have been observed in the study area according to Piper diagram. Most of the samples are of the type of $\mathrm{Ca}+2-\mathrm{Mg}+2-\mathrm{HCO}-3$. The samples collected at Gudur Thanda, Pagidipalli Village, Gudur Village, Anamptla Village, Erravattet Thanda, Gannegani Thanda, Makhdumpalli Village, Makhdumpalli Thanda, Gollaguda Village, Gollaguda Thanda, Ravipadu Village, Ravipadu Thanda, Anjpur Village, Madhram Village, Madhram Thanda 1 are $\mathrm{Ca}+2-\mathrm{Mg}+2-\mathrm{HCO}-3$. $\mathrm{Na}+\mathrm{HCO} 3-$ type distribution is observed in Madhram Thanda 2, Madhram Thanda 3, Srinikunta Village, Bommaipalli Village, Bollapalli gandinagar Thanda, Bollapalli gandinagar Village, Suryapalli Village, Nandanam Village and Nyamatupalli Village. Nyamatupalli Thanda, Erram palli Village, Tukkapuram Village, and Nagireddy palli Village are $\mathrm{Na}+-\mathrm{Cl}-$ type. The iper diagram for the analyses of groundwater samples is shown in fig.3.

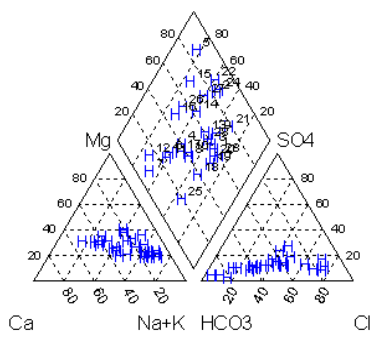

Fig. 3 Piper Diagram for the Groundwater samples in the Study Area
Wilcox diagram is drawn for the groundwater parameters in the study area in order to analyse the sodium adsorption ratio. It has been observed that $\mathrm{C} 3 \mathrm{~S} 1, \mathrm{C} 3 \mathrm{~S} 2, \mathrm{C} 3 \mathrm{~S} 3$ classification types are identified. C3S3 type classification is observed at Gudur Thanda, Pagidipalli Village, Gudur village, Anamptla Village, Erravattet Thanda, Gannegani Thanda, Makhdumpalli Village, Makhdumpalli Thanda, Gollaguda Village, Gollaguda Thanda, Ravipadu Village, Ravipadu Thanda, Anjpur Village, Madhram Village, Madhram Thanda 1, Madhram Thanda 2, Madhram Thanda 3, Srinikunta Village, Bollapalli gandinagar Village, Bollapalli gandinagar Thanda, Nagireddy palli Village, Nandanam Village, Nyamatupalli Thanda, Erram palli Village, Tukkapuram Village, and Bommaipalli Village. C3S2 type classification is observed at the Suryapalli Village and Nandanam Village and C3S3 type classification observed at Nyamatupalli Village. The salinity versus sodium absorption diagram for the analyses of groundwater quality parameters is shown in fig. 4

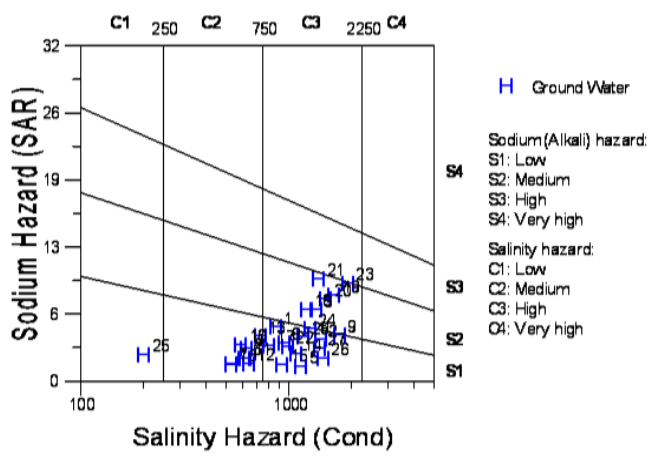

Fig.4 Wilcox Diagram for the Groundwater samples in the Study Area

\section{CONCLUSIONS}

For the groundwater samples collected in the study area the nitrate concentration values varied from 8-395.4 and the fluoride concentration values varied between 0.4-2.9. According to Piper diagram three types of classification namely $\mathrm{Ca}+2-\mathrm{Mg}+2-\mathrm{HCO}-3, \mathrm{Na}+-\mathrm{HCO} 3-$ and $\mathrm{Na}+-\mathrm{Cl}-$ are observed in the study area. 15 groundwater samples are of $\mathrm{Ca}+2-\mathrm{Mg}+2-\mathrm{HCO}-3$ type, 9 are $\mathrm{Na}+\mathrm{HCO} 3-$ type and remaining 4 groundwater samples are of $\mathrm{Na}+\mathrm{Cl}-\mathrm{type}$ of distribution. 53\% of the groundwater samples shows shallow meteoric percolation type, while $47 \%$ shows deep meteoric percolation type. The overall quality of groundwater in chinnaeru river basin was found to be good according to Piper diagram. According to Wilcox diagram three types of classifications namely $\mathrm{C} 3 \mathrm{~S} 1, \mathrm{C} 3 \mathrm{~S} 2, \mathrm{C} 3 \mathrm{~S} 3$ are observed in the study area. 21 samples are C3S1 classification type, 5 samples are $\mathrm{C} 3 \mathrm{~S} 2$ classification type and 2 samples are C3S3 classification type. From the Wilcox diagram it can be concluded that the groundwater available in the chinnaeru river basin is suitable for irrigation purpose. 


\section{REFERENCES}

[1] BIS, (1994), "Indian Standards Specifications for Drinking Water", Bureau of Indian Standards, IS: 10500 -1994).

[2] Central Pollution Control Board (1996), “Annual Report", 1994-95. New Delhi, pp135.

[3] Central Pollution Control Board (1996), “Annual Report", New Delhi, pp165.

[4] Mercer, M.W., and Morgan, C.O (1982), "Estimated use of water in the United States", U.S. Geological Survey Circular, 765, pp33.

[5] Murrary, C.R., and Reeves, E.B. (1975), "Estimated use of water in the United States", U.S. Geological Survey Circular, 765, pp33.

[6] Rao,Y.S., et al (1997), "Groundwater Quality in the Niva River Basin, Chittor District Andhra Pradesh", Journal of Environmental Geology, Vol.32, No.1, pp1-7.

[7] Subhramani,T., Elango, L., and Damodarsamy, S.R.,(2005), "Groundwater Quality and Its Suitability for Drinking and Agricultural use in Chithar River Basin, Tamil Nadu, India”, Journal of Environmental Geology, Vol. 47, No. 8, pp 1037-1178.

[8] Janardhana Raju, N., Prahlada Ram and Sangitha Dey, (2009), "Groundwater quality in the lower Varuna River basin, Varanasi district, Uttar Pradesh", Journal of the Geology Society of India, Vol. 73, No. 2, pp 157-294.

[9] Rakesh Kumar Tatawat and Singh chandel, C.P., (2008), "A Hydrogeochemical Profile for Assessing the Groundwater Quality of Jaipur City", Journal Environmental Monitoring and Assessment, Vol. 143, No.1-3, pp 337-343.

[10] Giridharan, L., Venugopaland, T., Jayaprakash, M., (2008), "Evaluation of the Seasonal Variation on the Geochemical Parameters and Quality Assessment of the Groundwater in the Proximity of River Cooum, Chennai, India”, Journal Environmental Monitoring and Assessment, Vol.143, No.1-3, pp161-178.

\section{BIOGRAPHY}

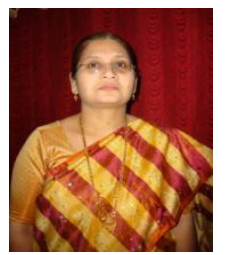

C. Sarala, Associate Professor, Centre for Water Resources, Institute of Science and Technology, Jawaharlal Nehru Technological University Hyderabad. Her research interest includes water resources analysis and environmental related problems 